\title{
Academic Performance of Enrolled Students in the University of Lahore, Pakistan
}

\author{
Sana Jawad ${ }^{1 *}{ }^{\oplus}$, Haleema Naveed $^{2} \odot$, Muhammad Bilal Akram $^{1} \odot$
}

Lecturer, University Of Management \& Technology, Lahore, Pakistan

2 Lecturer, Kinnaird College for Women, Lahore, Pakistan

* Corresponding Author (sanajawad199@gmail.com)

Received: 24 March, 2020

Revised: 16 October, 2020

Accepted: 11 November, 2020

Published: 15 December, 2020

How to cite this paper:

Jawad, S., Naveed, H., \& Akram, M.B. (2020). academic performance of enrolled students in the University of Lahore, Pakistan. Quest Journal of Management and Social Sciences, 2(2), 348-356.

Copyright (C) 2020 by authors and Quest Journal of Management and Social Sciences.

This work is licensed under a Creative Commons Attribution-Non Commercial-No Derivatives 4.0 International License. https://creativecommons.org/ licenses/by-nc-nd/4.0/

\section{Abstract}

Background: This study investigates the academic performance of students, enrolled at the University of Lahore, Pakistan to different programs in Spring-2019. The study measured the academic performance of students using the Cumulative Grade Point Average (CGPA). The variables under consideration were academic performance(students' percentage, CGPA, and GPA). A total number of nine hundred and fifty eight (958) students were enrolled in Spring-19 with CGPA's in Undergraduate BS (Hons) Programs, (246) Graduate (MS/MPhil.) Programs, and (11) Postgraduate (Ph.D.) Programs.

Objective: The report aims to identify the relationship between percentage of marks with undergraduates and graduates, enrolled at the University of Lahore, Pakistan to different programs in Spring-2019.

Methods: Undergraduate BS (Hons), Graduate (MS/M.Phil.) and Postgraduate $(\mathrm{PhD})$ students were taken as the target population for the research sample. Data were collected with the help of an array of technology support, and management. For analysis, the frequency analysis, descriptive analysis and correlation are used through the aid of Statistical Package for the Social Science (SPSS) version 23.

Results: Results show that the performance of students, enrolled with a weak academic background, had poor performance in enrolled programs. On the other hand, students, enrolled with high academic background, maintained their excellent performance in the first semester of their enrolled programs. Also, we observe that the students who were enrolled with a high percentage of marks show poor and average performance in the first semester.

Conclusions: We can infer from this analysis that only the students who were enrolled with a high percentage can achieve a high GPA in the semester. And likewise, students who weren't enrolled with a good percentage of marks cannot achieve a high GPA in the first semester.

Originality: This is the original work of author and not submitted for publishing in other publications.

Keywords: Academic Excellence, Technique of Learning, CGPA, University of Lahore.

Paper Type: Research Paper

JEL Classification: A22, A23, I26 


\section{Introduction}

Many factors can affect the academic performance of undergraduates and graduates. Past research has shown that good performance by students may be affected by the teaching and learning process, university infrastructure, family and peer influence, and the financial background of the students. Good academic performance of students will eventually lead to an increase in employment (Maharjan et al., 2020). For any educational institution, students are the most important assets. Without students, universities and colleges have no value. The economic and social development of a country is directly linked to the academic performance of students. The academic performance of students play a vital role in creating the best quality alumni, who will become leaders and manpower for the country, as a result (Paudel et al., 2018). Most of the previous research on student academic success concentrated on subjects such as teacher education, classroom settings and socioeconomic factors (Sabir et al., 2019). The majority of the scholars in the world use GPA to measure student success (Stephan \& Schaban, 2002). GPA was used to evaluate the performance of students in a particular semester. As Azmi et al. (2014) state, academic maturity, research abilities, time management skills and research anxiety were significant factors correlated with the academic success of the students.

Doménech-Betoret et al. (2017) showed that the expectation-value perception of the students played a role of a mediator between academic self-efficacy and the relationship of achievement. In addition, if the burden is sustained and viewed as unmanageable, it can lead to induce helplessness, depression and stress in students, thereby putting these students' career prospects at risk (McIntyre \& Francis, 2017). Correlation analysis was undertaken to assess the association between social support and academic performance of 272 students at Madonna University (Ogbeide \& Ugwu, 2016). Self-efficacy predicts academic success of students across academic fields and stages. Students with strong self-reliance are assured by following a lecture, addressing instructional challenges and choosing the most challenging courses (Sanchez, Outley, Gonzalez \& Cascante, 2018).

Academic performance in this study was characterized by success in assessments of previous and current academic performance in undergraduates, graduates and post graduates. This implies that the higher the previous results, the better the academic performance of the students. The students who are admitted in the university are from different social economic backgrounds and from different academic performance backgrounds. When they enter the university system, they are transformed by the management of the university through the teaching and learning process. The students' output is seen through their academic experience. The study aims to identify the performance of the undergraduates enrolled in the batch of spring 2019 at the University of Lahore, Pakistan.

The rest of the study is organized as: section 2 explains methodology used, followed by results and discussion in section 3 , and finally section 4 concludes the study with recommendation.

\section{Research Method}

The study's aim is to investigate factors that affect successes of students in primary school. It uses a conceptual framework, provided by the Nordin et al. (2012), for exploratory analysis on contributing factors to low academic achievement.

This work focuses on the fact that the students' success in intermediate evaluation is related to the description of the students, including their approach to communication, learning facilities, proper guidance and family tension (Mushtaq \& Khan, 2012). The goal of this analysis is to analyze the relationship between the students' previous and current scores that affect the academic performance of undergraduate, graduate and postgraduate students. It aims to assess if the previous performance has a major effect on their current GPA. It determines whether their previous performance have significant effect on their current GPA and their academic performance. The common assumptions are (i) students with a higher percentage of marks also secure higher GPA in their first semester, and (ii) students with lower percentage of marks also secure low GPA in their first semester. 


\section{Theoretical Framework}

Figure 1: Model for students' academic performance

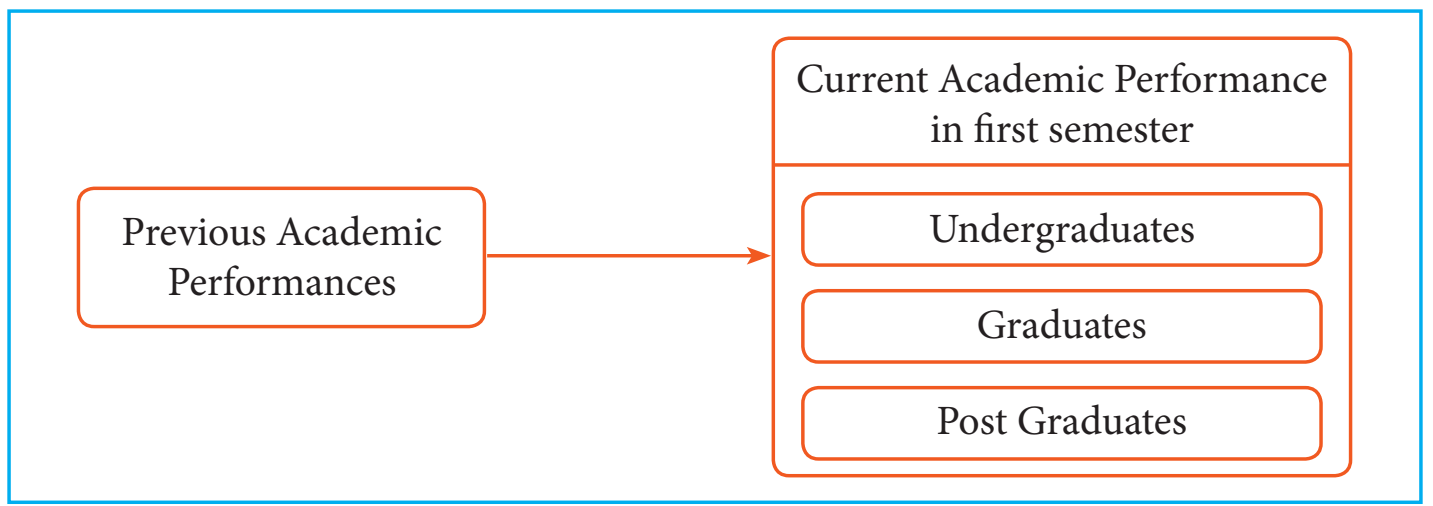

This study was conducted to analyze the various factors affecting the socioeconomic context and academic performance of undergraduate students enrolled at the private sector of the University of Lahore, Pakistan, in order to evaluate their individual successes and improvements. The examination includes comparative accomplishments of various UOL-Shariah \& Islamic Studies, Business Administration, Science \& Engineering, Arts \& Humanities and Law faculties.

\section{Study Area, Population and Sample}

The data were obtained from the office of University, using the basic random sampling method. 1477 students had enrolled in the batch of spring 2019 in with the degree programs Undergraduate BS (Hons), Master degree programs i.e. (M.com, M.A English, MBA(C), MBA(E), MCS(E), MHRM2Yrs and MSCM-2Yrs), MS/M.Phil., and Post-graduate $(\mathrm{PhD})$ from the different programs available in the University of Lahore, Pakistan (UOL). The research covers the period from the autumn of 2013 to the spring of 2014 academic year (Alam Billah, Arif -2014 \& Alam, 2014). The mean score was determined to assess students' analytical performance on each object. The research was conducted using a case study approach to analyze the previous academic performance and current GPA of these students. The results, frequency analysis, descriptive analysis, and correlation were completed with the use of the Statistical Package for the Social Science (SPSS) version 23.

A total number of 1318 students were included in the spring-19 (Student's Academic Performance) analysis report. Nine hundred and fifty-eight (958) students were enrolled in the Undergraduate BS (Hons) programs on the basis of their intermediate degree. Twenty eight (28) students were enrolled in the Master's degree programs i.e. (M.com, M.A English, MBA(C), MBA (E), MCS (E), MHRM2 Yrs and MSCM-2Yrs) on the basis of their four year degree program BS (Hons). Two hundred and forty-six (246) students were enrolled in MS/M.Phil. programmes on the basis of their four year degree programme BS (Hons). Seventy-five (75) students' were enrolled in M.Phil. Degree programs on the basis of their Master's degree. Eleven (11) students' were enrolled in the Post-graduate (PhD) programmes on the basis of their MS/M.Phil. One hundred and fifty-nine (159) students, with their marks recorded according to annual system, were not included in this study.

\section{Data Analysis and Results}

In this study, descriptive statistics for the main variables were computed for the entire sample, and correlation was used to check how the variables correlated with each other in either a positive or a negative way. The analysis tool used for data analysis is the SPSS 21 (Statistical Package for Social Sciences). 


\section{Student Enrollment Ratio}

This section consists of 958 undergraduate, 246 graduate and 11 postgraduate students, who are enrolled in spring-19 (figure 2). In the undergraduate programs, 53.3\% male students and $46.7 \%$ females students are enrolled, while the ratio, based on gender of enrollment, in the graduate programs, is almost same i.e. $50.4 \%$ of male students and $49.6 \%$ of female students. In the undergraduate level, the CGPA of the enrolled male students is recorded as higher than the grades of the female students. However, in graduate level, the marks of both the groups are almost equal. In the postgraduate level, the percentage of marks of the enrolled female students (63.6\%) is recorded as higher than those of the male students (36.4\%).

\section{Figure 1: Total enrollment in spring 2019}

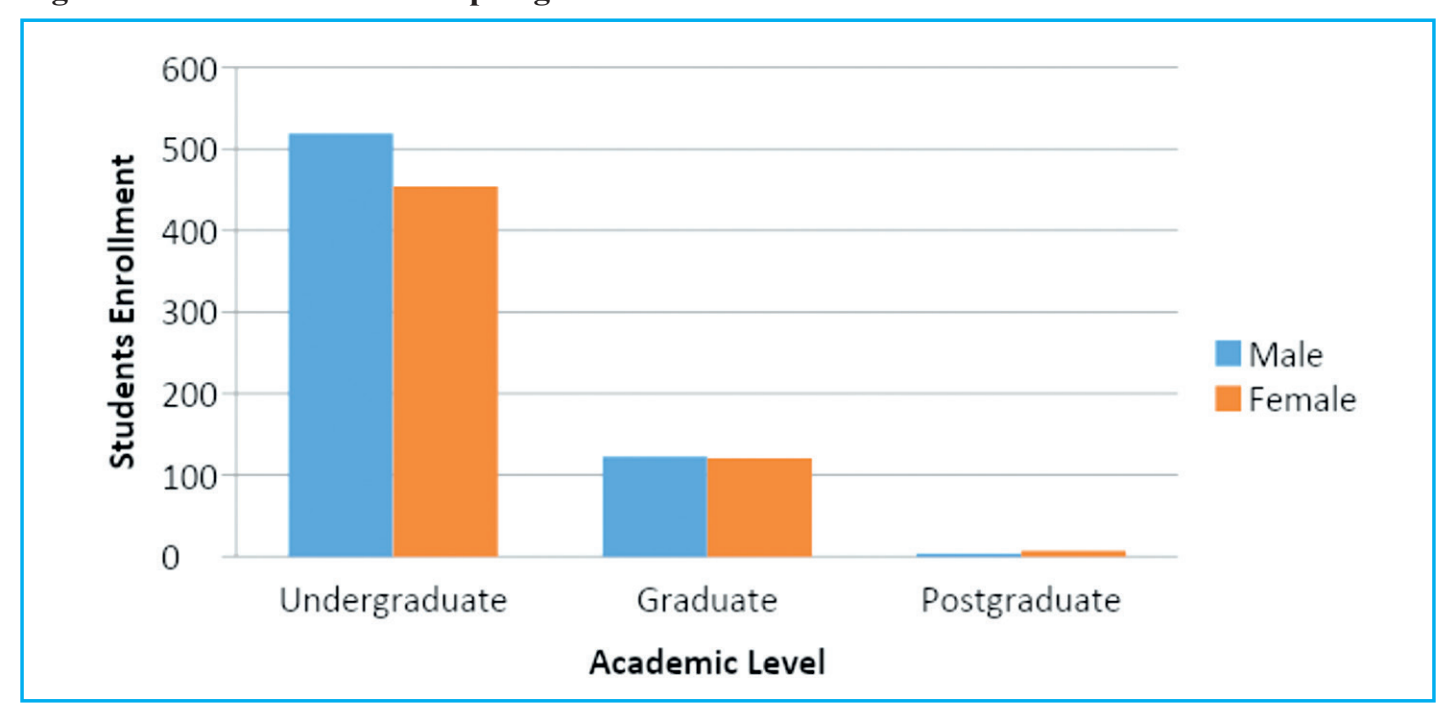

\section{Level wise Students' performance}

This section explores information of some quantitative variables related to the students' performance in the undergraduate level, the graduate level and the postgraduate level. Descriptive statistics shows all the academic performance of the spring-19 students from all levels, previous and current.

Table 1: Undergraduate Enrollment

\begin{tabular}{|c|c|c|c|c|c|c|c|c|c|c|c|c|}
\hline GPA (BS) & & & & & & Inter & ediate & & & & & \\
\hline GPA Slabs & $40-44$ & $45-49$ & $50-54$ & $55-59$ & $60-64$ & $65-69$ & $70-74$ & $75-79$ & $80-84$ & $85-89$ & $90-94$ & $95-100$ \\
\hline $\begin{array}{l}\text { Poor } \\
\text { Performer } \\
<\mathbf{1 . 0 0}\end{array}$ & & $36.4 \%$ & $27.3 \%$ & & $9.1 \%$ & $18.2 \%$ & & $9.1 \%$ & & & & \\
\hline $\begin{array}{l}\text { Below } \\
\text { Average } \\
\mathbf{1 . 0 1 - 1 . 5 0}\end{array}$ & $5.6 \%$ & $11.1 \%$ & $38.9 \%$ & $16.7 \%$ & $5.6 \%$ & $13.9 \%$ & $5.6 \%$ & & $2.8 \%$ & & & \\
\hline $\begin{array}{l}\text { Average } \\
1.51-2.00\end{array}$ & $1.8 \%$ & $22.8 \%$ & $23.7 \%$ & $22.8 \%$ & $13.2 \%$ & $7.0 \%$ & $4.4 \%$ & $3.5 \%$ & $.9 \%$ & & & \\
\hline $\begin{array}{l}\text { Good } \\
\text { Performer } \\
\mathbf{2 . 0 1 - 2 . 5 0}\end{array}$ & $2.2 \%$ & $21.2 \%$ & $30.7 \%$ & $13.0 \%$ & $14.3 \%$ & $7.4 \%$ & $5.6 \%$ & $4.3 \%$ & $.9 \%$ & $.4 \%$ & & \\
\hline
\end{tabular}


Very Good

Performer

2.51-3.00

$21.4 \% \quad 21.4 \% \quad 18.8 \% \quad 20.5 \% \quad 8.9 \% \quad 4.5 \% \quad 4.5 \%$

Excellent

Performer

3.01- 3.50

Meritorious

3.51- 4.00

$2.3 \%$

$9.1 \%$

$9.1 \%$

$9.1 \%$

We conclude from (Table 1) that the students who have enrolled in undergraduate programs' showing their performance are:

\section{Comments}

$<1.00$ GPA: $73 \%$ of students who have maintained poor performance at the university are those, who were enrolled with less than 55\% of marks in previous academic records.

1.51-2.00: GPA: $51 \%$ of students who have maintained average performance at the university are those, who had enrolled with less than $55 \%$ of marks in previous academic record.

2.51-3.00 GPA: $33 \%$ of students who have maintained very Good performance at the university are those, who had enrolled with less than $55 \%$ of marks in previous academic records.
1.01-1.50: GPA: $48 \%$ of students who have maintained below average performance at university are those, who had enrolled with less than $55 \%$ of marks in previous academic records.

2.01-2.50: GPA: $57 \%$ of students who have maintained good performance at the university are those who had enrolled in less than $55 \%$ of marks in previous academic records.

3.01-3.51: GPA: $18 \%$ of students who have maintained excellent performance at the university are those, who had enrolled in less than $55 \%$ of marks in previous academic records.

3.51-4.00: GPA: 5\% of students who have maintained excellent performance at the university are those, who had enrolled in less than $55 \%$ of marks in previous academic records.

Table 2: Graduate Enrollment

\begin{tabular}{|c|c|c|c|c|c|c|c|}
\hline \multirow{2}{*}{$\begin{array}{l}\text { M.S./M. Phil } \\
\text { GPA Slabs }\end{array}$} & \multicolumn{7}{|c|}{ Undergraduate CGPA } \\
\hline & $\begin{array}{l}<\mathbf{1 . 0 0} \text { Poor } \\
\text { Performer }\end{array}$ & $\begin{array}{c}\mathbf{1 . 0 1 - 1 . 5 0} \\
\text { Below } \\
\text { Average }\end{array}$ & $\begin{array}{l}\text { 1.51-2.00 } \\
\text { Average }\end{array}$ & $\begin{array}{c}\mathbf{2 . 0 1 - 2 . 5 0} \\
\text { Good } \\
\text { Performer }\end{array}$ & $\begin{array}{l}\mathbf{2 . 5 1 - 3 . 0 0} \\
\text { Very Good } \\
\text { Performer }\end{array}$ & $\begin{array}{l}\mathbf{3 . 0 1}-\mathbf{3 . 5 0} \\
\text { Excellent }\end{array}$ & $\begin{array}{c}\text { 3.51-4.00 } \\
\text { Meritorious }\end{array}$ \\
\hline$<\mathbf{1 . 0 0}$ Poor Performer & & & & & $60.0 \%$ & $40.0 \%$ & \\
\hline 1.01-1.50 Below Average & & & & $14.3 \%$ & $42.9 \%$ & $42.9 \%$ & \\
\hline 1.51-2.00 Average & & & & $5.6 \%$ & $50.0 \%$ & $38.9 \%$ & $5.6 \%$ \\
\hline 2.01-2.50 Good Performer & & & & $3.7 \%$ & $59.3 \%$ & $33.3 \%$ & $3.7 \%$ \\
\hline $\begin{array}{l}\text { 2.51-3.00 Very Good } \\
\text { Performer }\end{array}$ & & & & $9.1 \%$ & $49.1 \%$ & $30.9 \%$ & $10.9 \%$ \\
\hline 3.01-3.50 Excellent & & & & $2.9 \%$ & $44.1 \%$ & $35.3 \%$ & $17.6 \%$ \\
\hline 3.51-4.00 Meritorious & & & & $4.5 \%$ & $18.2 \%$ & $36.4 \%$ & $40.9 \%$ \\
\hline
\end{tabular}

We conclude from (Table 2) students who have enrolled in graduate (MS/M.Phil.) Programs' showing their performance are: 


\section{Comments}

$<1.00$ GPA: $100 \%$ of students who have maintained poor performance at the university are those, who were enrolled with 2.51-3.00 GPA in previous academic records.

$1.01-1.50$ GPA: $67 \%$ of students who have maintained below average performance at the university are those, who had enrolled with 2.513.00 GPA. And $33 \%$ of students with 3.51-4.00 GPA, in previous academic records, also have below average performance.

$1.51-2.00$ GPA: Students who have maintained average performance at the university were those who were enrolled with $6 \%$ of good, $57 \%$ of very well, $31 \%$ of excellent and $6 \%$ of meritorious marks in previous academic records.

$2.01-2.50$ GPA: Students who have maintained good performance at the university are those who were enrolled with $7 \%$ of good, $46 \%$ of very well, $40 \%$ of excellent and $7 \%$ of meritorious marks in previous academic records.

$2.51-3.00$ GPA: Students who have maintained very good performance at the university are those who were enrolled with $6 \%$ of good, $54 \%$ of very well, $33 \%$ of excellent and $7 \%$ of meritorious marks in previous academic records.

$3.01-3.51$ GPA: Students who have maintained excellent performance at the university are those who were enrolled with $1 \%$ of good, $44 \%$ of very good, $36 \%$ of excellent and $19 \%$ of meritorious marks in previous academic records.

3.51 - 4.00 GPA: Students who have maintained meritorious performance at the university are those who were enrolled with $3 \%$ of good, $20 \%$ of very well, $35 \%$ of excellent and $42 \%$ of meritorious marks in previous academic records.

Table 3: Postgraduate Enrollment

\begin{tabular}{|c|c|c|c|c|c|c|c|}
\hline \multicolumn{4}{|c|}{ PhD GPA. } & \multicolumn{4}{|c|}{ CGPA (MS/M.Phil.) } \\
\hline GPA Slab & $\begin{array}{c}<\mathbf{1 . 0 0} \\
\text { Poor } \\
\text { Performer }\end{array}$ & $\begin{array}{c}\mathbf{1 . 0 0}-\mathbf{1 . 5 0} \\
\text { Below } \\
\text { Average }\end{array}$ & $\begin{array}{l}\text { 1.51-2.00 } \\
\text { Average }\end{array}$ & $\begin{array}{l}\text { 2.01-2.50 } \\
\text { Good } \\
\text { Performer }\end{array}$ & $\begin{array}{c}\mathbf{2 . 5 1 - 3 . 0 0} \\
\text { Very Good } \\
\text { Performer }\end{array}$ & $\begin{array}{l}\mathbf{3 . 0 0}-\mathbf{3 . 5 0} \\
\text { Excellent } \\
\text { Performer }\end{array}$ & $\begin{array}{l}\text { 3.51-4.00 } \\
\text { Meritorious }\end{array}$ \\
\hline \multicolumn{8}{|l|}{$3.01-3.50$} \\
\hline $\begin{array}{l}\text { Excellent } \\
\text { Performer }\end{array}$ & - & - & - & - & - & $40.0 \%$ & $60.0 \%$ \\
\hline $\begin{array}{l}3.51-4.00 \\
\text { Meritorious }\end{array}$ & - & - & - & - & - & $50.0 \%$ & $50.0 \%$ \\
\hline \multicolumn{8}{|c|}{$\begin{array}{l}\text { We conclude from the (Table } 3 \text { ) students who have enrolled in Postgraduate }(\mathrm{PhD}) \text { programs' showing } \\
\text { their performance are: }\end{array}$} \\
\hline \multicolumn{8}{|l|}{ Comments } \\
\hline \multicolumn{4}{|c|}{$\begin{array}{l}3.00-3.50 \text { GPA: Students who have maintained } \\
\text { very good performance at the university are those } \\
\text { who were enrolled with } 67 \% \text { of lexcellent and } \\
33 \% \text { of meritorious marks in previous academic } \\
\text { record. }\end{array}$} & \multicolumn{4}{|c|}{$\begin{array}{l}3.51-4.00 \text { GPA: Students who have maintained } \\
\text { meritorious performance at the university are } \\
\text { those who were enrolled with } 13 \% \text { of very well, } \\
25 \% \text { of excellent and } 63 \% \text { of meritorious marks } \\
\text { in previous academic records. }\end{array}$} \\
\hline
\end{tabular}

Correlation Analyze between the Undergraduate, Graduate and Postgraduates Students'

The analysis of the correlation among variables is explained in table 4, 5, 6 below, The study found, in Table 4, that the academic performance of the students showed strong positive associations between their academic performance in their intermediate and undergraduate levels. As indicated in Table 5, the 
performance of undergraduates and the current performance of graduates also had positive correlation between them. However, as shown in Table 6, there is no association between the performance of the graduates and the present performance of the postgraduates.

Table 4, 5 and 6: Correlation Analysis between the Undergraduate, Graduate and Postgraduates Programs.

\begin{tabular}{lccc}
\hline Table 4 & & & \\
\hline & & Intermediate & Undergraduate \\
Intermediate & Pearson Correlation & 1 & $.470^{* *}$ \\
Undergraduate & Pearson Correlation & $.470^{* *}$ & 1 \\
\hline Table 5 & & Undergraduate & Graduate \\
\hline & Pearson Correlation & 1 & $.177^{* *}$ \\
Undergraduate & Pearson Correlation & $.177^{* *}$ & 1 \\
Graduate & & & \\
\hline Table 6 & & Graduate & Postgraduate \\
\hline & Pearson Correlation & 1 & .120 \\
Graduate & Pearson Correlation & .120 & 1 \\
Postgraduate & & & \\
\hline
\end{tabular}

**. Correlation is significant at the 0.01 level (2-tailed).

\section{Discussions}

This study intends to examine the previous academic performance of the students. The first question was whether the students enrolled with low percentages received good GPA in the first semester. Through this study, we concluded that majority students enrolled with low performance have shown excellent results with good GPA/CGPA. The second issue was to check the performance of the students enrolled with high performance or grades in their previous academic backgrounds. Through this analysis, it was concluded that some students enrolled with high grades have shown mediocre or poor results in their semester, while some students managed to maintain their good GPA/CGPA in their first semester.

According to the analysis, it has been identified that the university does not follow their admission criteria. Some students have been enrolled with less than 2.5 CGPA. To maintain the criteria and improve the quality of education, the university needs to follow their admission policies. Therefore, we see in table 4 that the intermediate and undergraduate students' performance are positively correlated. This means that the students who are enrolled in the undergraduate programs improve their performance in the first semester. Similarly, we can see in table 5 that the undergraduate and graduate students' performance are also positively correlated, meaning that these students programs to improve their performance in the first semester. In the same table, we can see that the students who maintained their performance had enrolled in postgraduate programs with either a poor or an excellent GPA/CGPA.

\section{Conclusion}

This study was carried out to investigate the relationship between the previous academic performance and current educational performance of undergraduates, graduates and postgraduate students, enrolled to different programs at the University of Lahore (UOL), in Pakistan in the spring-2019 session. The study reveals the positive relationship between undergraduate and graduate academic performance, and no correlation between graduate and postgraduate students' academic performance. 
Despite less CGPA in their previous academic programs, most students showed better performance in their current academic programs. However, some students showed poor performance as well. This finding is similar to that of Malik \& Singh (2016). They reveal that the effects of learning facilities, communication skills and adequate feedback from parents on the students' academic success are positive and statistically important. The research used systematic association methodology to identify and calculate the degree of the relationships. Within this method, the scores of subjects are calculated on two variables, without any variables being changed, to decide whether there is an association (Creswell, 2014).

It is concluded from the analysis that the University is rigorously enforcing admission criteria in accepting students in their academic programs, especially for the undergraduate and graduate levels. In spite of the application of admission criteria, lists of students were extracted from the graduate data who were enrolled in the academic programs on the basis of their undergraduate academic records. Some students were enrolled in the graduate degree program with less than 2.5 CGPA, which do not meet the requirements of MS/MPhil. Degree.

Based on the findings, the study presents the following recommendations. Applicants must satisfy all applicable guidelines and fulfill admission requirements established at university. Student must demonstrate an ability to maintain a satisfactory level of performance in academic program. The student must execute a written agreement incorporating their degree requirements and mutual responsibilities. The agreement must be executed before the student can be enrolled in the program. The university shall expel a student for failure to meet the responsibilities and standards in the agreement. During the admission process, a test should be conducted by the university. Applicants need to compete for securing an admission at the university. In order to pass the test, students have to obtain at least $50 \%$ marks. The university should rigorously enforce their admission criteria and testing. Extracurricular activities such as speech league, sports, and many others should be set as priority because they provide great opportunities to interact with new people and improve the students' social skills.

\section{Conflict of Interest}

No conflict of interest existed between authors while preparing this article.

\section{References}

Alam, M. M., Arif Billah, M., \& Alam, M. S. (2014). Factors affecting academic performance of undergraduate students at International Islamic University Chittagong (IIUC), Bangladesh. Journal of Education and Practice, 5 (39), 143-154.

Azmi, N., Ali, A. M., Wong, X.-L., Kumolosasi, E., Jamal, J. A., \& Paraidathatu, T. (2014). Internal factors affecting academic performance among pharmacy students in Malaysian Institute of Higher Learnings. Indian Journal of Pharmaceutical Education and Research, 48 (3), 26-33.

Creswell, J. (2014). Research Design: Qualitative, Quantitative, and Mixed Methods Approaches: SAGE Publications

Doménech-Betoret, F., Abellán-Roselló, L., \& Gómez-Artiga, A. (2017). Self-efficacy, satisfaction, and academic achievement: The Mediator role of students' expectancy-value beliefs. Frontiers in Psychology, 8, 1193.

Maharjan, S., Devkota, N., Paudel, U. R., Bhandari, U., \& Adhikari, K. (2020). MBA graduates' perception on job search sources: Evidence from Nepal. Asian Journal of Economics, Business and Accounting, 16(3), 30-40.

McIntyre, T. M., McIntyre, S. E., \& Francis, D. J. (2017). Educator Stress: An Occupational Health Perspective: Springer International Publishing. 
Mushtaq, I., \& Khan, S. N. (2012). Factors affecting students' academic performance. Global Journal of Management and Business Research, 12 (9), 17-22.

Ogbeide, E., \& Ugwu, C. (2016). Relationship between social support and academic performance among undergraduate students of Madonna University, Nigeria. Global Journal of Applied, Management and Social Sciences (GOJAMSS), 13, 70-77.

Paudel, U. R., Devkota, N., Ghale, B. A., \& Adhikari, K. (2018). Communication and gender in bachelor's degree students' adjustment process: A study in Kathmandu, Nepal. Journal of Education, Society and Behavioural Science, 27(4), 1-9.

Rasetimela, M. (2016). Factors that influence the performance of students in botswana primary schools. IOSR Journal of Humanities and Social Science (IOSR-JHSS), 9 (5), 40-53.

Rasul, S., \& Bukhsh, Q. (2011). A study of factors affecting students' performance in examination at university level. Procedia Social and Behavioral Sciences, 2042-2047.

Sabir, F. S., Maqsood, Z., Tariq, W., \& Devkota, N. (2019). Does happiness at work lead to organization citizenship behavior with mediating role of organization learning capacity? A gender perspective study of educational institutes in Sialkot, Pakistan. International Journal of Work Organization and Emotion, 10(4), 281-296.

Sanchez, H., Outley, C., Gonzalez, J., \& Cascante, D. (2018). The influence of self-efficacy beliefs in the academic performance of latina/o students in the United States: A systematic literature review. Hispanic Journal of Behavioral Sciences, 40(2), 176 - 209.

Shahrina, M. N., Ahmad, W., Fatimah, W., Nayan, M. Y., Yahya, N., Azrai, A., \& Othman, Y. (2012). A conceptual framework in examining the contributing factors to low academic achievements: self-efficacy, cognitive ability, support system and socio-economic.

Singh, S. P., Malik, S., \& Singh, P. (2016). Research paper factors affecting academic performance of students. Indian Journal of Research, 5(4), 176-178. 